\title{
A Mini Review on the Studies of Gastrointestinal Tract of Teleost Fishes in Indian Subcontinent
}

\author{
Subuhi Abidi and Iqbal Parwez* \\ Department of Zoology, India \\ *Corresponding author: Iqbal Parwez, Department of Zoology, Aligarh, UP-202002, India
}

Submission: 眥 August 02, 2018; Published: 酱 November 09, 2018

\begin{abstract}
A large body of information exists on the variety of teleost fishes which abound Indian subcontinent. The present review summarizes in chronological order of the research carried by various investigators on the teleost fishes of this important region. Efforts have also been made to identify the knowledge gaps and the strategy to fill such lacunae. Expectedly, this review will serve as a ready source of document to have an overview of the existing information of the GIT on the extant teleost fishes of Indian subcontinent.
\end{abstract}

Keywords: Histomorphology; Gastrointestinal tract; Teleost fishes; Indian subcontinent

\section{Introduction}

The gastrointestinal system (GIT) has evoked considerable interest amongst anatomists and physiologists due to notable correlation of the GIT structural features with the dietary habits of the organism. Hence, large number of studies have been carried out on the morphology, anatomy and histology both at light and ultrastructural level of the various segments of the GIT of variety of fish species and the existing literature on this aspect has been extensively reviewed by many workers from time to time [1-8]. The Indian subcontinent abounds with large piscine biodiversity harboring nearly 2300 different fish species and the survey of literature reveals that a good number of extant teleost fishes of Indian subcontinent have been extensively studied.

It is, therefore, desirable that the existing information on the GIT of the fishes of Indian subcontinent must be reviewed and documented to serve as a reference point of the cumulative source of literature for the workers in this important area. The critical appraisal of the documented literature in this area suggests that there has been a gradual evolution of knowledge of the structural details of GIT which was dependent upon the availability of the analytical tools and techniques. It is worthwhile to mention that one of the earliest documented study on GIT of Indian fishes was carried out by Sarbahi [9] on the morphology of Lebeo rohita, an important herbivorous fish which was followed by another study of Mohsin [10] on the morphology of the GIT of a carnivorous fish Anabas testudines. Thereafter, a long gap of nearly one decade existed during which no major study on the GIT of Indian fish species was documented in literature.

The subsequent period of $60 \mathrm{~s}$ and 70 s witnessed a resurgence of interest on the studies of GIT of Indian fishes by different workers
[11-19] but such studies were mostly confined to morphology of predominantly carnivorous fishes belonging to either carp or airbreathing catfish. At this point, it is important to acknowledge the voluminous contribution made by Khanna [20] who gave a comparative account of GIT of large number of teleost fishes of Indian subcontinent. Such studies were further extended by the same group to include aspects like comparative account and histomorphology, distribution of taste buds and mucous secreting cells of bucco-pharyngeal region and morphology and histology of intestine of Indian Teleostei [21-26]. During the period of 19501970 , an overwhelming number of studies were carried out on anatomy and histology of GIT based exclusively on feeding habits i.e. carnivores, herbivores and omnivores categories.

The studies of Pasha [27-29] on three different fishes i.e. Megalops cyprinoides, Tilapia mosammbica \& Mystus gulio with aforesaid different feeding habits i.e. deserve special mention. Most of the contemporary workers also focused on specific GIT segment-based studies such as on single or comparative account of oesophagus, stomach and intestine to highlight the morphological and functional significance of each region of GIT of the fishes such as Mystus seenghala [12], M vittatus [30], Colisa fasciata [19] \& Anabas testudineus [4]. Interestingly, most of these studies remained confined to either carps or air-breathing fishes which may be due to their wider abundance and economic significance. A limited number of studies were carried out mostly on Indian major carps like Labeo rohita [31], Catla catla [14], Cirrhina mrigala [32] \& Labeo calbasu [33] describing their GIT changes concomitant with various life cycle stages of these fishes. Literature pertaining to the histochemical localization of mucopolysaccharides and some enzymes on the various segments of GIT is limited [34] and often confined to the anterior part of the GIT. 
Moreover, no concerted effort has been made to localise various cell types associated with the secretion of digestive juices which facilitate the process of digestion. More focused studies on large number of Indian teleosts are warranted to fill the existing lacuna of knowledge on this important aspect. Abidi \& Parwez [35] described the qualitative differences in the glycoconjugates moiety in oesophagus of Heteropneustes fossilis where neutral glycoprotein was predominantly present with certain amount of acidic moiety. The comparative study of gastric mucosa of Mystus cavasius, Oreochromis niloticus \& Gudusia chapra, revealed the predominant presence of neutral glycoprotein suggesting thereby the neutralised effect of acid environment on the superficial layer [36].

In order to get an idea of the finer structural details of the internal surface area of GIT, Sinha and co-workers have carried out extensive SEM studies largely on Indian major carps and catfishes [37-43] and similar studies have been made on snow trout Schizothorax curvifrons by Mir \& Channa [44], Mystus vittatus, Liza parsia \& O. mossambicus by Chakarbarti \& Ghosh [45] and H. fossilis by Samanta et al. [46]. Curiously, this reviewer has come across only one study on the TEM details of the GIT of Indian catfish $H$. fossilis \& O. niloticus by Samanta et al. [47]. It seems clear from the above details that morphohistological and anatomical features of the alimentary canal of different Indian Teleostei are well documented. However, the great degree of variations in the structural details of the GIT are inevitable largely due to the great diversity in the piscine fauna and also the variations in the dietary habits of the fishes.

\section{Conclusion}

Following the first documented report on the GIT of Indian Teleostei in 1939, a long gap with virtually no reported studies existed. However, there was a sudden resurgence of interest on this important aspect where the studies were mostly confined to morphology of predominantly carnivorous group of fishes belonging to either carp or air breathing catfishes. Subsequent studies were focused on histo-morphological distribution of taste buds and mucous secreting cells. Literature pertaining to histochemicaly localization of mucopolysaccharides and some enzymes have been mostly confined to anterior part of GIT. In the later years, most of the studies were carried out on the anatomy and histology of GIT in relation to the feeding habits of the fishes. Some attention has also been paid to studies relating to localization of glycoconjugates while the studies on ultrastructural details of the various segments of GIT are limited and more studies are warranted including those on the presence of different types of lectins in various regions of alimentary canal.

\section{References}

1. Andew W (1959) Textbook of Comparative Histology. Oxford University Press, New York, USA.

2. Harder W (1975) Anatomy of fishes. In: Schweizerbart'sche E (Ed.), Verlagsbuchhandlung, Stuttgart, UK.

3. Kapoor BG, Smit H, Verighina IA (1975) The alimentary canal and digestion in teleost. Adv Mar Biol 13: 109-239.
4. Ray AK, Moitra SK (1982) On the morpho-histology of the alimentary tract in the Indian Climbing Perch, Anabas tastudineus (Bloch), in relation to food and feeding habits. Gegenbaurs Morphol Jahrb 128(5): 778-798.

5. Zihler F (1982) Gross morphology and configuration of digestive tracts of Cichlidae (Teleostei, Perciformes): phylogenetic and functional significance. Neth J Zool 32: 544-571.

6. Kapoor BG, Khanna B (1993) The potential spectrum of the gut in teleost fishes. Adv Fish Biol 1: 221-226.

7. Stevens ED, Hume ID (2004) Comparative physiology of the vertebrate digestive system, Cambridge University Press, Cambridge, UK, p. 400.

8. Wilson JM, Castro LFC (2011) Morphological diversity of the gastrointestinal tract in fishes. In: Grosell M, Farrell AP, Brauner C (Eds.), Multifunctional Gut of Fishes. J Fish Physio 30: 1-55.

9. Sarbahi DS (1939) The alimentary canal of Labeo rohita (Ham.) J Roy Asia Soc Bengal Sci 5(2): 87-116.

10. Mohsin SM (1946) The morphology and histology of alimentary tract of Anabas testudineus. J Oamania Univ 12: 66-75.

11. Kapoor BG (1957) The digestive tube of an omnivorous cyprinoid fish, Barbus stigma (CUV and VAL). Jap J Ichthyol 6(3): 48-53.

12. Sarkar HL (1959) Studies on the morpho-histology of the digestive system in relation to the food and feeding habits in a siluroid fish Mystus (Osteobagrus) seenghala (Sykes). Proceedings of the Zoological Society 12: 97-109.

13. Rastogi RK (1966) The morphology and histology of the alimentary canal of Heteropneustes fossilis (Bloch). Agra Univ Res Sci 16: 63-72.

14. Moitra SK, Bhowmik ML (1967) Functional histology of the alimentary canal of the young Catla catla (Ham.), an omnivorous surface feeding fish of Indian freshwater. Vestnik Cs Spol Zool 31: 41-50.

15. Singh R (1967) Studies on the alimentary canal of Ophicephalus marulius. Ibid 16: 27-38.

16. Mehrotra BK, Khanna SS (1969) Histomorphology of the oesophagus and the stomach in some Indian teleosts with inference on their adaptational features. Zoologische Beitrage 15: 375-391.

17.Gupta OP (1971) Studies on the morphology, histology and the swallowing mechanism of the digestive tract of a carnivorous fish Xenentodon cancila (Ham.). Okajimas Fol anat jap 48(1): 29- 51.

18. Sastry KV, Goel KA (1974) Morphology and histology of the alimentary canal of Ophiocephalus (Channa) punctatus in relation to its feeding habit. Folia Morphol (Praha) 22(4): 362-371.

19. Moitra SK, Ray AK (1977) Morpho-histology of the alimentary canal of an Indian freshwater perch, Colisa fasciata (Bloch) in relation to food and feeding habits. Anat Anz 141(1): 37-58.

20. Khanna SS (1961) Alimentary canal in some teleostean fishes. J Zoo So India 13: 206-219.

21. Khanna SS (1962) A study of bucco-pharyngeal region in some fishes. Ind J Zoot 3: 21-48.

22. Khanna SS (1964) Histology of the digestive tract of a teleost, Clarias batrachus (L.). J Zool Soc India 16: 53-58.

23. Khanna SS (1968) The structure and distribution of the taste buds and the mucus secreting cells in the buccopharynx of some Indian teleosts (Pisces). Studies, DSB Goverment College, Nanital, India 5: 143-148.

24. Khanna SS, Mehrotra BK (1970) Histomorphology of the buccopharynx in relation to feeding habits in teleost. Proc Nat Acad Sci India 40: 61-80.

25. Khanna SS, Mehrotra BK (1971) Morphology and histology of the teleostean intestine. Anat Anz Bd 129(1): 1-18. 
26. Khanna SS, Pant MC (1964) On the digestive tract and the feeding habits of some teleostean fishes. Agra Univ Journ Res (Sci) 13: 15-30

27. Pasha SMK (1964a) The anatomy and histology of the alimentary canal of an omnivorous fish, Mystus gulio. Proc Ind Acad Sci 59(4): 211-221.

28. Pasha SMK (1964b) Anatomy and histology of the alimentary canal of a herbivorous fish, Tilapia mosambica. Proc Ind Acad Sci 59B: 340-349.

29. Pasha SMK (1964c) The anatomy and histology of the alimentary canal of a carnivorous fish, Megalops cyprinoides. Proc Ind Acad Sci 60B: 107115.

30. Agarwal VP, Sharma U (1966) Morpho-histological studies of the digestive tract of Mystus vittatus. Proc Nat Acad Sci India 36: 441-456.

31. Kamal MY (1967) Studies on the food and alimentary canal of the Indian major carps II Labeo rohita (Ham) and III Cirrhina mrigala (Ham.) Indian J Fish 14: 24-47.

32. Sinha GM, Moitra SK (1975) Morpho-histology of the intestine in a freshwater major carp, Cirrhinus mrigala (Ham.) during the different life history stages in relation to food and feeding habits. Anat Anz 137(4): 395-407.

33. Sinha GM (1976) Comparative morphology, anatomy and histology of the alimentary canal of an Indian freshwater major carp, Labeo calbasu (Ham.) during the different life-history stages in relation to food and feeding habits. Anat Anz 139(4): 348-362.

34. Banerjee G, Ray AR (2018) The effect seasonal temperature on endogenous gut enzyme activity in four air-breathing fish species. Croat J Fish 76(2): 60-65.

35. Abidi S, Parwez I (2015) Histomorphology of oesophagus and histochemicaly characterization of oesophageal mucin of the catfish Heteropnestes fossilis. Int J Fish Aquat 3(1): 199-204.

36. Ghosh SK, Chakrabarti P (2015) Histological and histochemical characterization on stomach of Mystus cavasius (Hamilton), Oreochromis niloticus (Linnaeus) \& Gudusia chapra (Hamilton): Comparative study. J Basic Appl Zool 70: 16-24.

37. Sinha GM (1981) Scanning electron microscopy of the intestine in an Indian freshwater major carp, Cirrhinus mrigala (ham.). J Inland Fish Soc India 13: 51-56.
38. Sinha GM (1983) Scanning electron microscopy of the intestinal mucosa of an Indian freshwater adult major carp, Labeo rohita (Ham.). Z Mikrosk-anat Forsch Leipzig 97: 979-992.

39. Sinha GM, Chakrabarti P (1985) On topological characteristics of the mucosal surface in buccopharynx and intestine of an Indian freshwater major carp, Catla catla (Ham.): A light and scanning electron microscopy study. Zool Jb Anat 113: 375-389.

40. Sinha GM, Chakrabarti P (1986) Scanning electron microscopy studies on the mucosa of the digestive tract in Mystus aor (Ham.). Proc Ind Nat Sci Acad 52(2): 267-273.

41. Sinha GM, Chakrabarti P (1989) Micro-architecture of the gut epithelium in Labeo calbasu (Ham.): Scanning electron microscopy study. Arch Biol Bruxelles 100: 283-294.

42. Chakrabarti P, Mandal DK, Ganguly S (1992) A scanning electron microscope study of the mucosal epithelium of the alimentary canal of stomach bearing herbivorous fish Oreochromis mossambicus (Peters). Eur Arch Biol 103: 265-270.

43. Mondal DK, Chakrabarti P (1996) Architectural pattern of mucosal epithelium of the alimentary canal of Notopterus notopterus (Pallas) and Oreochromis mossambicus (Peters): A comparative study. Acta Ichthyol Piscat 26: 15-23.

44. Mir IM, Channa (2010) A scanning electron microscopic examination of the intestinal tract of the snow trout schizothorax curvifrons heckel. J Fish Aquat Sci 5(5): 386-393.

45. Chakrabarti P, Ghosh SK (2014) A comparative study of the histology and microanatomy of the stomach in Mystus vittatus (Bloch), Liza parsia (Hamilton) and Oreochromis mossambicus (Peters). J Microsc Ultrast 2(4): 245-250.

46. Samanta P, Pal S, Mukhetjee AK, Ghosh AR (2016) Pathological (Histological and Ultrastructural) study in stomach and intestine of Heteropneustes fossilis (Bloch) to Excel mera 71, a Glyphosate-based herbicide. J Gastrointest Dig Syst 6(6): 1-5.

47. Samanta P, Pal S, Mukhetjee AK, Ghosh AR (2016) Gastrointestinal pathology in freshwater fish, Oreochromis niloticus (Linnaeus) Under Almix exposure. J Environ Anal Toxicol 6(5): 1-6.

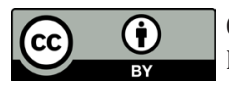

Creative Commons Attribution 4.0

International License

For possible submissions Click Here

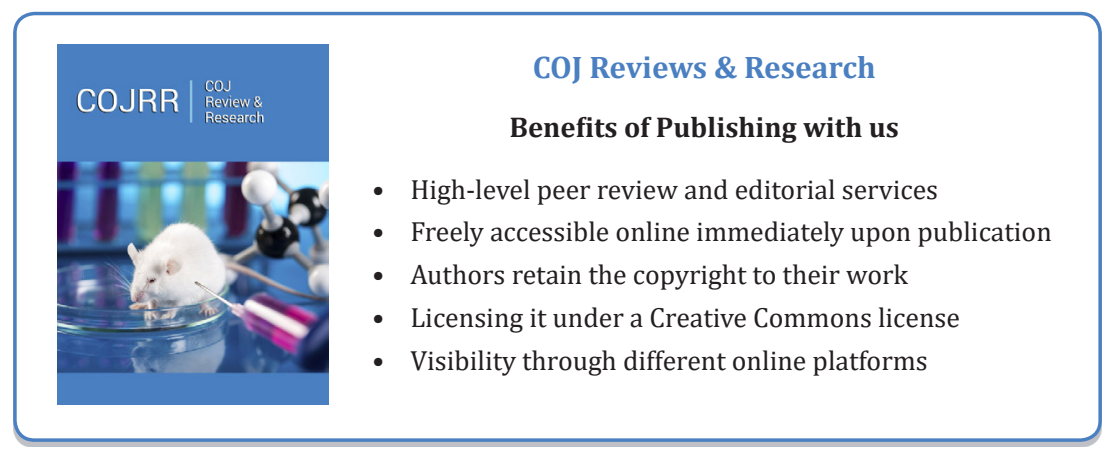


